\title{
THE ECOLOGICAL VISION OF SPACE IN GARY SNYDER'S ECOPOETRY
}

\author{
Arvind Dahal*
}

\begin{abstract}
The paper seeks to investigate the ecological vision of Space in Gary Snyder's ecopoetry which exclusively exposes how humans have modified the planetary space naively and accelerated it greatly in the name of promoting technology and consumption oriented industrial economy. Snyder's ecopoetry is a poetic response to the growing environmental concerns and he aims to reconnect humans to nature in the face of a threatened world. Snyder's poems; "The Berry Feast", "Mid-August at Sourdough Mountain Lookout", "By Frazier Greek" and "Riprap"areanalyzed in the light of his "Deep Ecological" movement and the central environmental problem of Space which reminds us that our planetary space is limited, and the growing threats to that space require us to reconsider our relationship to that space and use of it. My contention in this paper is to argue that Snyder views the boundary made between humans and nonhumans, place and non-place as hubristic in nature because humans are still insouciant about where the boundaries originated. Theoretical insights from Henri Lefebvre, Lawrence Buell, Martin Heidegger, HomiBhaba, Marc Auge, Yi-Fu Tuan and Gary Snyder reframe the relationships of humans to the natural world, in this paper. Their conceptions of those relationships are premised on a particular idea of space as boundaried: this is the human world and that is the natural one.
\end{abstract}

Keywords: Anthropocentrism, Deep- Ecology, Ecocriticism, Territorialization

Environmental concerns are overwhelmingly the concerns of space. Human beings ask pertinent questions like: Is there enough space for the expanding world population? Is there enough space to grow or raise the food supply that the population requires? Is there enough space for our garbage? These questions are the part of current discourses on nature and culture because "our planetary space is limited, and the growing threats to that space requires us to reconsider our relationship and the use of it" (Buell 77). The ecopoetry of Gary Snyder has emerged as a poetic response to these growing environmental concerns. His poetry seeks to reimagine the connections among living things in such a way as to encourage activism and "environmental responsibility" (Buell 79).

In order to understand the boundaries, Snyder's imposition on space in his poetry focuses on the conception of the origin of boundaries. The idea of space as boundaried emerges from the human experience of the world. Yi-Fu Tuan, a cultural geographer, investigates place, space and their relation to each other and to our human condition. He explains how humans learn space prior to understanding place: * Assistant Professor of Saraswati Multiple Campus (Humanities Faculty: English Department), Tribhuvan University,
Nepal. 
Biology conditions our perceptual world.... The infant has no world. He cannot distinguish between self and an external environment. He feels, but his sensations are not localized in space. The pain is simply there, and he responds to it with crying; he does not seem to locate it in some specific part of his body. (Tuan 20)

As infants develop, Tuan explains they begin to orient themselves to understand forward, backward, up, down. This sense of the self in space becomes an understanding of place in space. Lawrence Buell summarizes the relationship of space and place as, "space to which meaning has been ascribed" (72). Henri Lefebvre indicates that the idea of home evokes a concern for maintaining boundaries. Places, like homes, necessitate a kind of protection of the periphery. Place is one kind of place. Another field is the work we do, our calling, our path in life. Membership in a place includes membership in a community. With Lefebvre's idea that places require protection is one that has excited the eco-minded writers and critics. Lawrence Buell states, “.... an awakened sense of physical location and of belonging to some sort of place-based community have a great deal to do with activating environmental concern" (78). Gary Snyder takes up this idea and employ boundary tactics as a method of conveying this care for place, and sharing a protectivistinstinct for space which was primordial, with the readers. For Snyder Space is Wilderness or the natural world which should be protected.

Gary Snyder uses names to make the world his home. His range of specificity swings from simple proper nouns within prepositional phrases. For instance By Frazier Creekwhich gives the speaker's location in relation to the place. Snyder's basic concept of nature involves a deep interconnectedness to the point where the human realm is not separate from nature as a whole. He has followed his own doctrine of reinhabiting the country by living in his self-built house on the foothills of Sierra Nevada. Similarly, Snyder includes time elements like "Mid August" in MidAugust at Sourdough Mountain Lookoutto show that humans are anthropocentric which controls, determines and circumscribes those places with which they are familiar but relegate other places which they donot know. In ecology, man is by virtue of his biological constitution part of nature, thus inextricably intertwined with everything that surrounds him, be it animals and plants he feeds on, air he breathes or forests and rivers. This idea has brought humans insouciance towards nature:

When a person feels out of place, as travelers often do, the next best thing can be a predictably safe space where you feel, buffered against the weirding-out effect of a strange locale. Better to travel the world via a succession of nonplaces than to risk being stranded, robbed, etc. (Buell 71)

Anthropological theorist Marc Auge emphasizes the idea of "nonplace" as the clinical settings which are more attractive to humans, "the experience of non-place is its power of attraction, inversely proportional.... to the gravitational pull of place and tradition" (qtd. in Buell, 69). Snyder's place- making extends beyond just proper noun in titles; he also creates places by going to them. For Snyder, the natural world is somewhere one has to go. The titles Snyder uses indicates natural spaces, creeks, falls, mountain, Alaska, and he imagines these areas are different from the rest of the so called civilized, territorialized world. For example, he writes in Mid-August at Sourdough Mountain Lookout: 
I cannot remember things I once read

A few friends, but they are in cities

Drinking cold snow-water from a tin cup

Looking down for miles

Through high still air. (6-10)

The speaker's position is given in the title and this second stanza indicates that the natural place he occupies is distanced from other people, who are in cities. He has escaped the city to get to a natural place that he can occupy himself and name both spatially and temporally. He has written this poem from wilderness. The poem locates the speaker in a natural space "as opposed to a civilized space and allows the downward gaze of his position from the lookout onto the landscape" (Morse 5) to illustrate the distance between those two places: I am in this place, and they are in that place, and there is a journey between them. The distance separating the two places aids in protecting the natural place from civilization. In the poem By Frazier Creekthe distance between the two places and the vantage point that allows the speaker to look down on the wilderness scene also enable him to reflect on what humans are capable of, on the power humans have to live outside of civilization:

\author{
Standing up on lifted, folded rock \\ Looking out and down- \\ The creek falls to a far valley \\ hills beyond that \\ facing, half-forested, dry \\ -clear sky (1-6)
}

The poem opens with a clear framing of the narrator's position: "standing up" and "looking out and down". From this perspective, the landscape is explored by the eye. Land causes the speaker to realize what is possible:

\author{
we are it \\ it sings through us- \\ We could live on this Earth \\ without clothes or tools! (16-19)
}

The very tendency of humans to exploit nature has brought environmental crisis. Snyder argues for the reciprocity of humans and space. This notion of space is shown in the poem The Berry Feasthe introduces the pastoral world of huckleberries which are a lot organic and tastier than the American breakfast. The berries are scattered by birds and found in bear droppings, as part of a mutually beneficial ecological space:

Spread through the air by birds;

Find them in droppings of bear

stopped in the night

Ate hot pancakes in a bright room. (94-97) 
Snyder argues that eventhough the birds and bears eat the berries, they are also participating in spreading the berries seeds. He wants us to realize, nature knows how to keep herself fed. Human behavior is anthropocentric and human waste is useless, but the berries and their seeds have natural cycle which helps the environmental space. He wants us to wake up and see the wilderness and break the boundaries.

Likewise, in the poem Ripraphe presents landscape from bottom-up perspective. He is building out of rocks the path that will connect the speaker to the natural place he wishes to reach:

$$
\begin{aligned}
& \text { Lay down the woods } \\
& \text { Before your mind like rocks, } \\
& \text { placed solid, by hands } \\
& \text { In choice of place, set } \\
& \text { Before the body of the mind } \\
& \text { in space and time: } \\
& \text { Solidity of bark, leaf, or well } \\
& \text { riprap of things.... (1-8) }
\end{aligned}
$$

Snyder points to natural place he is differentiating from the example of space. Once the place has been created through the poem's opening, he suggests that all these places must be gone to: "The world like an endless/ four-dimensional/ Game of Go"(15-17). The fact that the place must be reached indicates that the space nature occupies is boundaried and specific. Travel, departure and arrival, requires place to leave from and go to and the path between them establishes their positionality.

From the above analysis of Snyder's poem in the light of space foregrounds the concept that stable, centralized place-making allows boundaries to develop. As long as nature is located outside of civilization, as long as humans are considered to be outside of nature the environmental crisis remains a problem as the concept of space has not changed due to human insouciance. Buell cautions that:

If every place on earth were cared for as we like to think 'a protected' reserve is cared for, then perhaps the health of planet and people might be secured. But taking a good thing too far(place attachment and stewardship at the local level) manifestly can produce bad results too. (Buell 68)

The natural world is not sequestered from the inhabited one. They are integrated and overlaid upon each other. So, there must be conscientious shifting from place to make space. Snyder reimagines the relationship is his ecopoetry the dissolution of boundaries and the possibility of interrelatedness of place and space. Snyder views the created boundary between humans and nonhumans, place and non-place as hubristic in nature because humans are still insouciant about where the boundaries originated.He wants us to realize, nature knows how to keep herself fed. Human behavior is anthropocentric. 


\section{Works Cited}

Buell, Lawrence. Space, Place, and Imagination from Local to Global.Malden, MA: Blackwell Publishing, 2005. 62-96.

Lefebvre, Henri. Critique of Everyday Life. New York: Kirkpatric Press, 1990. Web. 10 Aug. 2016.

Morse, Jenny. The ecopoetics of Gary Snyder. Illinois: University of Illinois Press, 2010. Web. 9 Aug. 2016.

Snyder, Gary. The Gary Snyder Reader: Prose, Poetry and Translations. New York: Counterpoint, 1999. Web. 7 Aug. 2016.

Tuan, Yi- Fu. Space and Place: The Perspective of Experience. Minneapolis: University of Minnesota. Press, 1977. Web. 9 Aug. 2016. 